comparable information for younger age groups. Our findings suggest that falling in women at perimenopausal ages deserves particular attention.

1 Alffram P, Bauer (GCH. Epidemiology of fractures of the forearm. 7 Bone foin Surg 1962;44A:105-1t.

Miller SWM, Grimley Evans J. Fractures of the distal forearm in Newcastle: an epidemiological survey. Age Ageing 1985; 14:155-8.

Prudham D, Grimlev Evans J. Factors associated with falls in the elderly: a community study. Age Ageing 1981;10:141-6.

Todd J, Butcher B. Electoral registration in 1981. London: Office of Population Censuses and Survers, 1982.

Campbell AJ, Spears GFS, Borrie MJ, Fitzgerald JL. Falls, elderly women, and the cold Gerontolog, 1988:34:205-8.
6 Tinetti ME, Speechley M, Ginter SF. Risk factors for falls among elderl persons living in the community. N kingl f Med 1988:319:1701-7.

Campbell AJ, Reinken J, Allan BC, Martinez GS. Falls in old age: a study of frequency and related clinical factors. Age Ageing 1981;10:264-70.

8 Blake AJ, Morgan K, Bendall MJ, et al. Falls by elderly people at home: prevalence and associated factors. Age Ageing 1988:17:365-72.

9 Zarkovich SS. (uality of statistical data. Rome: Food and Agriculture Organisation of the United Nations, 1966.

Melton LJ, Riggs BL. Risk factors for injury after a fall. Clin Geriatr Med 1985;1:525-36.

11 Bungay (IT Vessey MP, McPherson CK. Studs of ssmptoms in middle life with special reference to the menopause. Br. Med f 1980;281:181-3.

Accepted 5 April 1989
Department of

Endocrinology, Royal Free Hospital Medical School, London NW3 2QG Jean Ginsburg, DM, senior lecturer in endocrinology

Paul Hardiman, MRCOG, clinical research fellow

Barbara O'Reilly, PHD,

technical research assistant

Correspondence to: $\mathrm{Dr}$ Ginsburg.

Br Med f 1989;298: 1488-90

\title{
Peripheral blood flow in menopausal women who have hot flushes and in those who do not
}

\author{
Jean Ginsburg, Paul Hardiman, Barbara O’Reilly
}

\section{Abstract}

Objective-To compare blood pressure, heart rate, and peripheral vascular responsiveness in menopausal women who have hot flushes and in those who do not, and to assess the effect on these variables of treating women who have hot flushes with oestriol, a natural oestrogen, given vaginally.

Design-An open, non-randomised cohort study of flushing and non-flushing menopausal women. A before and after investigation of the effects of vaginal oestriol treatment on the circulation.

Setting-Referral based endocrinology clinic.

Patients -88 Consecutive menopausal women, 63 complaining of frequent hot flushes and 25 who had not flushed for at least a year.

Intervention-Treatment with vaginal oestriol 0.5 mg at night for six weeks in $\mathbf{1 8}$ of the women who had hot flushes.

Measurements and main results - Peripheral blood flow was measured by venous occlusion plethysmography at rest and in response to stressful mental arithmetic and anoxic forearm exercises. Blood flow in the forearm and its variability were significantly higher in flushing than in non-flushing women $(4 \cdot 1$ (SD 1.7) and 3.1 (0.9) $\mathrm{ml} / 100 \mathrm{ml}$ tissue $/ \mathrm{min}$ and $17 \%$ and $13 \%$ respectively). Blood pressure, heart rate, and blood flow in the hand were, however, similar in the two groups. No difference was found in the peripheral incremental response to either stress or anoxic exercise. Vaginal oestriol significantly lowered forearm blood flow from $4 \cdot 4(1 \cdot 5)$ to $3 \cdot 3(1 \cdot 1)$ $\mathrm{ml} / 100 \mathrm{ml}$ tissue $/ \mathrm{min}$ but dilator responsiveness was unaffected.

Conclusions-The peripheral circulation is different in menopausal women who have hot flushes compared with those who do not, with selective vasodilatation in the forearm. The lowered blood flow in the forearm after vaginal oestriol in flushing women may be relevant to the alleviation of vasomotor symptoms induced by oestrogen treatment.

\section{Introduction}

Although menopausal hot flushes are the commonest symptoms of the climacteric, occurring in around $70 \%$ of women,' why some women flush frequently for years while others never flush or do so only for a short time is not understood. Women with severe symptoms at the climacteric are said to be more likely to be hypertensive or to have episodes of high blood pressure than those who do not flush frequently. ${ }^{2}$ There are, however, no critical studies to substantiate such beliefs.
We previously showed that the symptoms of menopausal flushes are accompanied by objective changes: a rapid but transient increase in blood flow through the arm and in pulse rate, ${ }^{3}$ the pattern of change resembling that seen in response to indirect heating of the body. + This suggests that the flush may reflect inappropriate activation of the mechanisms for heat loss and may explain why menopausal women often complain of feeling hot and why hot flushes may be precipitated or aggravated by vasodilator stimuli such as drinking a hot drink, stress, and a rise in ambient temperature.

Because of this and the fact that clonidine, an $u$ agonist prescribed for relief of menopausal flushing, reduces dilator responses to exogenous vasoactive amines, ${ }^{6}$ partly through influencing peripheral vasodilator responsiveness, ${ }^{7}$ we compared vascular responsiveness in menopausal women who had frequent hot flushes with that in women of the same age who either had never flushed or had not experienced flushes for at least a year.

\section{Patients and methods}

Circulatory studies were performed in 88 menopausal women who had had their last menstrual period at least six months earlier and whose follicle stimulating hormone concentration was raised into the menopausal range ( $>20 \mathrm{IU} / \mathrm{l})$. Of these, 63 complained of hot flushes, whose frequency ranged from three to 40 a day (mean $10 \cdot 2$ a day). The remaining 25 either had never flushed or had not done so for at least a year. The mean age of the flushing and non-flushing women was similar: 50.1 (SD 8.6) and $51.9(8.5)$ years respectively $(p>0.05)$. There was no difference in the time since menopause between the two groups.

The women were all clinically and biochemically euthyroid. None had taken oestrogens in the preceding 12 months, and none was taking any drug affecting cardiovascular activity at the time of the investigation. Informed consent was obtained from each subject.

Blood flow in the forearm and in the hand was measured by venous occlusion plethysmography under standardised laboratory conditions, as in previous studies. ${ }^{36-11}$ Blood pressure and heart rate were recorded with an automatic recorder (Electro Medical Equipment, Brighton). Pulse rate was also calculated directly from the plethysmographic tracing as required. The precise position of the plethysmograph in relation to the styloid process of the radius was noted at the first laboratory visit and used in subsequent tests. Subjects were tested at least two hours after a light meal. 
Blood flow was measured every 15 to 30 seconds, except when the blood flow changed rapidly and recordings were then made every 10 seconds. The mean resting blood flow was calculated from consecutive measurements of flow over at least three to four minutes. The standard deviation of mean blood flow was calculated from the repeated flow measurements made throughout a recording session and divided by the mean flow on that occasion. This gives the coefficient of variation, a measure of the variability in blood flow through the arm.

Responses to dilator stimuli-stressful mental arithmetic and anoxic arm exercise - were determined as in previous studies. ${ }^{10}$ The circulatory effects of treatment with a natural oestrogen - oestriol-given through the vagina $(0.5 \mathrm{mg}$ at night $)$ for at least six weeks were also investigated.

Differences between mean data were assessed by Student's $t$ test for paired and unpaired samples as appropriate. A two tailed $\mathrm{p}$ value of $<0.05$ was regarded as significant. In the case of the coefficients of variation the $t$ test was applied to the logarithms of the individual data.

\section{Results}

BLOOD PRESSURE AND PULSE RATE

No significant difference in blood pressure or pulse rate was found between the 63 flushing and 25 nonflushing women, the respective means being 128/79 and $123 / 76 \mathrm{~mm} \mathrm{Hg}$ and 79 and 82 beats/min.

\section{BLOOD FLOW}

The mean blood flow in the forearm was significantly higher $(\mathrm{p}<0.005)$ in the women who had flushes than in those who did not, being $4 \cdot 1(1 \cdot 7)$ and $3 \cdot 1(0 \cdot 9) \mathrm{ml} /$ $100 \mathrm{ml}$ tissue $/ \mathrm{min}$ respectively. The difference between the mean flow values in the two groups was 1.0 with a $95 \%$ confidence interval of $0 \cdot 3$ to $1 \cdot 7$.

The mean coefficient of variation in forearm flow was also significantly higher in women who had flushes, being $16.9 \%$ and $12.9 \%$ respectively $(p<0.02)$. The difference between the sample means in the two groups was 4.0 with a $95 \%$ confidence interval of 0.8 to $7 \cdot 2$.

There was, however, no significant difference in blood flow in the hand or in its mean coefficient of variation between flushing and non-flushing women, the respective means being $10 \cdot 8(6 \cdot 7)$ and $13 \cdot 0(6 \cdot 2) \mathrm{ml} /$ $100 \mathrm{ml}$ tissue $/ \mathrm{min}$ and $24 \cdot 5 \%$ and $24 \cdot 9 \%$.
RESPONSE TO STRESSFUL MENTAL ARITHMETIC

The response to stressful mental arithmetic was studied in 15 flushing and 13 non-flushing women (figure). The raised flow of blood in the forearm of women who had hot flushes was sustained during the vasodilatation evoked by stressful mental arithmetic, the difference in forearm flow between the two groups remaining significant throughout $(\mathrm{p}<0 \cdot 05)$. The mean resting blood flow was $4 \cdot 2(0 \cdot 5)$ and $2 \cdot 6(0 \cdot 2) \mathrm{ml} / 100 \mathrm{ml}$ tissue/min in flushing and non-flushing women respectively, increasing to $6.5(0.9)$ and $4.3(0.3) \mathrm{ml} / 100 \mathrm{ml}$ tissue/min during stressful mental arithmetic and falling to $4.7(0.7)$ and $2.8(0.2) \mathrm{ml} / 100 \mathrm{ml} / \mathrm{min}$ respectively after the period of stress. Although the increase in blood flow in the forearm above the resting mean during stressful mental arithmetic was no greater in women who had flushes, thereafter the flow fell to baseline values more slowly in the women with flushes and remained significantly raised $(p<0.05)$ above their resting mean value.

Blood flow in the hand fell to a similar extent in both groups during the stress of mental arithmetic $(12.2$ $(1.5)$ and $12.3(1.7) \mathrm{ml} / 100 \mathrm{ml}$ tissue/min in women who had flushes and those who did not respectively).

Mental arithmetic also increased pulse rate significantly. The mean rise was similar in the two groups. In women with hot flushes it was $73 \cdot 1(3 \cdot 0)$ beats/min initially, $84 \cdot 4(4 \cdot 1)$ during stressful mental arithmetic, and $75 \cdot 1(3.0)$ thereafter, and in women who did not have hot flushes the corresponding values were 66.9 $(2 \cdot 5), 79 \cdot 3(3 \cdot 9)$, and $69 \cdot 7(2 \cdot 8)$ beats/min respectively.

\section{RESPONSE TO LOCAL ANOXIC EXERCISE}

The response to anoxic exercise was assessed in 22 flushing and 12 non flushing women. No significant difference was found between the two groups in peak forearm flow $(11.1 \mathrm{ml} / 100 \mathrm{ml}$ tissue $/ \mathrm{min}$ in women who had flushes and $13.2 \mathrm{ml} / 100 \mathrm{ml}$ tissue $/ \mathrm{min}$ in those who did not; $p>0.5$ ); the rate of fall in flow from peak values and the time taken to reach resting values were also similar.

\section{CIRCULATORY EFFECTS OF VAGINAL OESTRIOL TREATMENT}

The circulatory effects of at least six weeks' vaginal oestriol treatment were assessed in 18 flushing women. This treatment rapidly relieved symptoms such as hot flushes and vaginal dryness but, as previously reported, induced no change in either blood pressure or heart

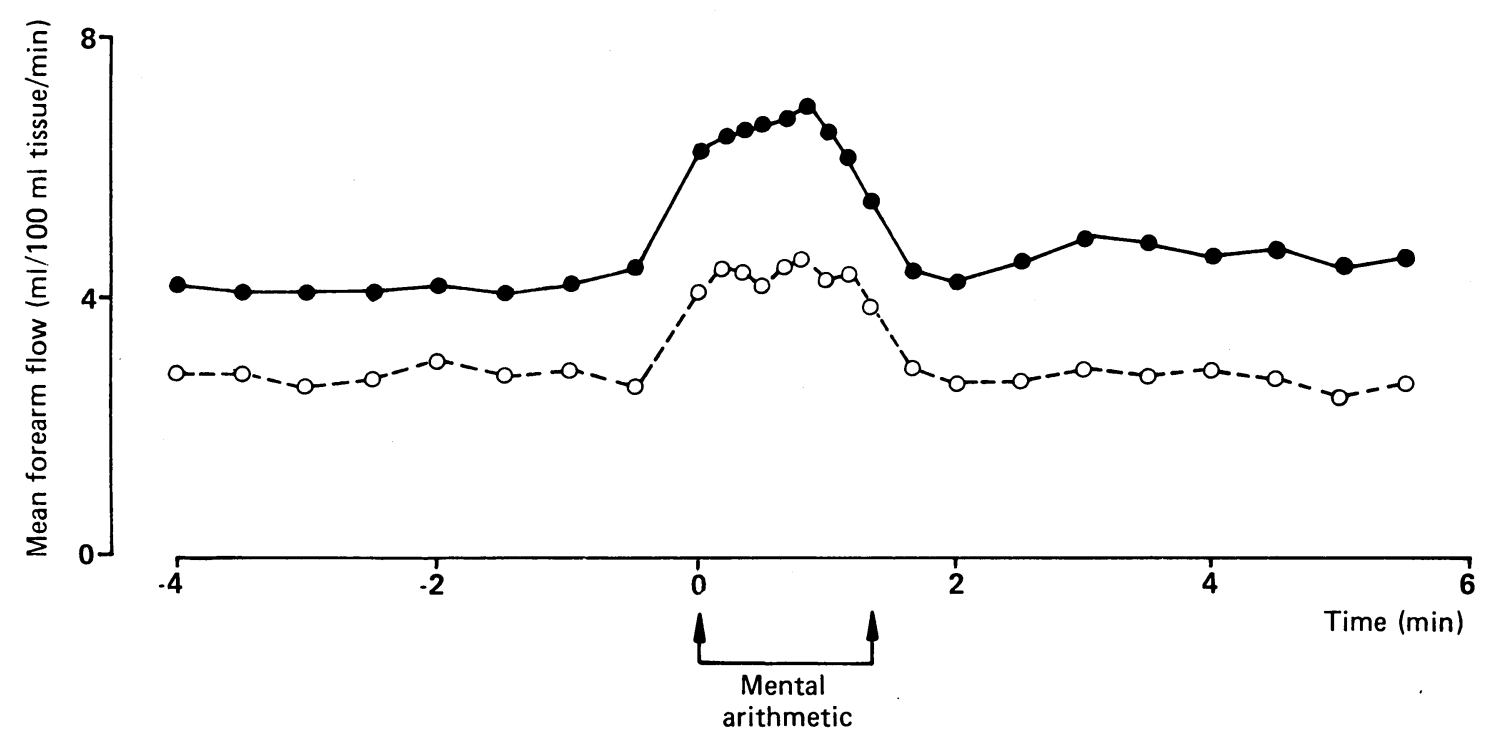

Mean forearm blood flow before, during, and after stressful mental arithmetic in 15 menopausal women who had hot flushes (•) and 13 who did not (O) 
rate, the respective means being $129 / 86 \mathrm{~mm} \mathrm{Hg}$ and 64.6 beats/min initially and $126 / 80 \mathrm{~mm} \mathrm{Hg}$ and 61.9 beats/min after at least six weeks' vaginal oestriol treatment.

Forearm blood flow, however, fell significantly after vaginal oestriol treatment from $4 \cdot 4(1 \cdot 5)$ to $3 \cdot 3(1 \cdot 1) \mathrm{ml} /$ $100 \mathrm{ml}$ tissue $/ \mathrm{min}$. The difference between the sample means was 1.1 with a $95 \%$ confidence limit of 0.2 to $2 \cdot 0$. The variability in forearm flow was not significantly changed $(p>0 \cdot 1)$, the mean values being $16.5 \%$ before and $16 \cdot 5 \%$ during treatment.

Neither basal hand flow nor the coefficient of variation in blood flow in the hand were influenced by vaginal oestriol treatment, averaging $11 \cdot 4(4 \cdot 8) \mathrm{ml} / 100$ $\mathrm{ml}$ tissue $/ \mathrm{min}$ and $27 \cdot 0 \%$ respectively before treatment and $10.5(3.8) \mathrm{ml} / 100 \mathrm{ml}$ tissue $/ \mathrm{min}$ and $26.0 \%$ after six weeks' vaginal treatment.

\section{Discussion}

Our finding of a significantly higher blood flow in the - forearm in menopausal women who flush than in their symptomless peers shows that there is an objective change in physiological function in women who suffer from menopausal flushes. As blood pressure was similar in the two groups the higher flow recorded in the women who had hot flushes was not the result of a change in systemic arterial pressure. Similarly, as blood pressure is not lower in women who flush frequently their raised forearm flow does not reflect a generalised increased flow through skeletal muscle. The raised blood flow in the forearms of flushing women is most likely due to a selective increase in flow through the arterioles of forearm skin. The fact that the coefficient of variation in forearm flow was higher in women with hot flushes may also be explained by increased skin flow as flow through vessels in the skin is more variable, even at rest, than that through muscle arterioles. Studies of blood flow in forearm skin with strain gauge plethysmography" are therefore in progress.

Although the raised flow of blood in flushing women was sustained during the vasodilatation induced by stressful mental arithmetic, the increment in flow was similar in the two groups and there was no inherent increased distensibility of forearm blood vessels in the women who had hot flushes, the vasodilatation evoked by anoxic local exercise being similar to that in nonflushing women. We also observed that forearm flow in flushers remained raised during the vasodilatation induced by both adrenaline and noradrenaline. ${ }^{2}$ It is of particular interest that flow remained higher in women who had hot flushes during the transient first phase of adrenaline dilatation, which is a purely local effect of adrenaline. This suggests that there may be a local change in vascular responsiveness to adrenaline.

The most commonly prescribed treatment for the symptoms of the climacteric is a synthetic preparation of oestrogen given orally. Our decision to study the effects of a natural oestrogen, oestriol, given vaginally ${ }^{13}$ was to simulate ovarian secretion and eliminate the unphysiological alterations-for example, in the lipid profile and renin-angiotensin system - that are inevitable after oral treatment. ${ }^{1+15}$ That blood flow in the forearm fell after vaginal oestriol, so that by six weeks the flow was similar to that in women who did not have hot flushes is therefore interesting. One of us (BO'R) also found a reduction in the dilator response to both stressful mental arithmetic and catecholamine infusion after vaginal oestriol treatment. ${ }^{12}$ Oestradiol influences adrenergic receptors and responsiveness to catecholamines in various animal tissues, including the uterus, ${ }^{16}$ ovary,,$^{17}$ brain, ${ }^{18}$ and lung,,$^{19}$ as well as blood vessels. ${ }^{20}$ Does oestriol similarly affect the blood vessels of skeletal muscle?

We cannot, however, assume that all substances alleviating hot flushes necessarily act in the same way. Thus clonidine, an $\alpha$ agonist that may reduce the intensity and even the frequency of hot flushes, ${ }^{21}$ does not alter resting blood flow in the $\mathrm{arm}^{6}$ and, in contrast to oestriol, affects the dilator response to anoxic exercise. Hot flushes are associated with peripheral vasodilatation and may be precipitated or aggravated by dilator stimuli; we have shown an alteration in peripheral vascular activity in women who have hot flushes compared with those who do not. One of the essential prerequisites for the onset of flushing might therefore be a change in peripheral vascular tone. If we knew how and why this occurred we might be able to determine why only $70 \%$ of menopausal women have hot flushes and why they are short lived in others. Such information would help in devising treatment for these distressing symptoms.

BO'R was supported by the British Heart Foundation and PH by the Stanley Thomas Johnson Foundation. Technical help was provided by Miss L McGregor, who is supported by the Stanley Thomas Johnson Foundation.

1 McKinlay SM, Jeffreys SM. The menopausal syndrome. British fournal of Preventive and Social Medicine 1974:28:108-15.

2 Hoffman CH. Das Verhalten des diastolischen Blutdrucks bei Frauen mit klimakterischen Wallungen im Steh- und Belastungsversuch [Inaugural Dissertation]. University of Wurzburg: Wurzburg, 1965.52 pp.

3 Ginshurg J, Swinhoc J, O'Reilly B. Cardiovascular responses during the menopausat hot flush. Brf Obstet Gynaecol 1981;88:925-30.

+ Kerslake D McK, Cooper KE. Vasodilation in the hand in response to heating the skin elsewhere. Clin Sci 1950;9:31-47.

Barcroft $\mathrm{H}$, Bonnar W McK, Edholm OG. Reflex vasodilation in human skeletal muscle in response to heating the body. F Physiol (Lond) 1947;106 $271-8$.

6 Ginshurg J, O'Reilly B, Swinhoe J. Effect of oral clonidine on human vascular responsiveness: a possible explanation of the therapeutic action of the drug in menopausal flushing and migraine. Br $\mathcal{F}$ Obstet Gynaecol 1985;92: $1169-75$.

7 Ginshurg J, Hardiman P. Adrenergic agonists for menopausal complaints. In: Genazzani AR, Montemagno U, Nappi C, Petraglia F, eds. The brain and the female reproductive ssstem. Carnforth: Parthenon, 1987:623-5.

8 (iinshurg J. Observations on the peripheral circulation in hypertrophic pulmonary osteoarthropathy. Qf Med 1958;27:335-52.

9 Ginsturg J, O'Reilly. B. Effect of oral clonidine on the vascular effects of stressful mental arithmetic in menopausal women. $\mathcal{F}$ Cardiovasc Pharmacol 1987;10:162-5.

10 Duncan SLB, Ginsburg J. Arteriolar distensibility in hypertensive pregnancy. Am. Y Obstet Gynecol 1968;100:222-9.

11 Clarke RSJ, Ginsburg J, Hellon RF. Use of the strain gauge plethysmograph in assessing the effect of certain drugs on the blood flow through the skin and muscle of the forearm. F Phvsiol (L.ond) 1958;140:318-6.

12 O'Reilly B. Circulatory responses in menopausal women. [PhD Thesis]. London: University of London, $1985.307 \mathrm{pp}$

13 Fink RS, Collins W'P, Papadaki L, O'Reilly B, Ginsburg J. Vaginal estriol: effective menopausal therapy not associated with endometrial hyperplasia. foumal of Gynecologv and Endocrinology 1985;1:1-11.

14 Fahraeus L. Potency and hepato-cellular effects of oestrogens after oral, percutaneous and subcutaneous administration. In: van Keep PA, Utian percutaneous and subcutaneous administration. In: van Keep PA, Utian
WH, Vermeulen A, eds. The controversial climacteric. Lancaster: MTP, 1981:103-25.

15 Laragh JH, Sealey JE, Ledingham JCG, Newton MA. Oral contraceptives. Renin, aldosterone, and high blood pressure. FAMA 1967;201:918-22.

16 Bottari SP, Vokaer A, Kaivez. E, Lescraninier JP, Vauquelin GP. Differential regulation of alpha adrenergic receptor subclasses by gonadal steroids in human myometrium. F Clin Endocrinol Metab 1983;57:937-41.

17 Jordan AW. Changes in ovarian adrenergic receptors during the estrous cycle of the rat. Biol Reprod 1980;24:245-8.

18 Wagner HR, Crutcher KA, Davis JN. Chronic oestrogen treatment decrease heta-adrenergic responses in rat cerebral cortex. Brain Res 1979;171:147-51.

19 Moawad AH, River LP, Kilpatrick SJ. The effect of estrogen and progesterone on beta-adrenergic receptor activity in rabbit lung tissue. Am $\mathcal{J}$ Obstet Ginecol 1982;144:608-13.

20 Colucci WS, Gimbrone Jr JA, Alexander RW. Estrogens, sympathectomy and catecholamines regulate the vascular alpha-adrenergic receptor. Clin Res 1980;28:162A.

21 Clayden JR, Bell JW, Pollard P. Menopausal flushing: double-blind trial of a non-hormonal medication. $\operatorname{Br} M e d$ f 1974; ; :409-12.

(Accepted 10 April 1989) 